\title{
Molecular characterization of local strains of Bacillus thuringiensis in the North of Algeria
}

\author{
Kebdani M. ${ }^{1 *}$, Mahdjoubi M. ${ }^{2}$, Cherif A. ${ }^{2}$, Gaouar B. N. ${ }^{1}$ and Rebiahi S. A. ${ }^{3}$ \\ ${ }^{1}$ Laboratory of Ecology and Management of Naturals Ecosystems, Ecology and Environment Department, Abu Bakr \\ Belkaid University, Imama, Tlemcen, Algeria. \\ ${ }^{2}$ Laboratory of Biotechnology and Bio-Geo Resources Valorization, Higher Institute for Biotechnology, University of \\ Manouba Biotechpole of Sidi Thabet Sidi Thabet, Ariana, Tunisia. \\ ${ }^{3}$ Laboratory of Applied Microbiology and Environment, Biology Department, Abu Bakr Belkaid University, Imama, \\ Tlemcen, Algeria.
}

Received 1 February, 2016, Accepted 19 September, 2016.

\begin{abstract}
The analysis of soil samples taken from orange groves located in four cities of Northern Algeria allowed the isolation and identification of 24 strains belonging to the group Bacillus cereus, based on their physiological, biochemical and molecular characters investigated. They were divided as follow: 12 strains of Bacillus thuringiensis, 1 strain of Bacillus pumilis, 4 strains of Bacillus cereus, 5 strains of Bacillus subtilis and 2 Bacillus mycoides strains. After the molecular characterization performed with the aid of polymerase chain reaction (PCR) analysis, it was confirmed from the parasporal bodies using a scanning electron microscope that the strains of the identified collection belong to the species, $B$. thuringiensis.
\end{abstract}

Key words: Bacillus cereus, Bacillus thuringiensis, Bacillus pumilis, Bacillus subtilis, Bacillus mycoides, polymerase chain reaction, scanning EM.

\section{INTRODUCTION}

Phytophagous insects contribute largely to the decrease of agricultural productivity. Their management is generally based on the use of chemical pesticides which have certain benefits, but at the expense of human health and environment (Rice et al., 2007). Likely, the massive and systematic use of these products leads to the emergence of resistant genotypes (Kranthi et al., 2001; Pray et al., 2002; Shelton et al., 2002). Biological control is defined as the reduction of pest populations by natural enemies, which are naturally present in most ecosystems and can be used voluntarily in agriculture among others, as a replacement for conventional pesticides.

Bacillus thuringiensis (Bt) commercial bio-control agents are used for the management of certain insect pests. This bacterium belonging to the Bacillus cereus group is a Gram-positive bacillus of about $1 \mu \mathrm{m}$ wide and 3 to 5 microns long; it is optionally aerobic/ anaerobic with ovoid spores, not deforming, and located in a central position or subterminal, at the rate of one spore per cell (Guinebretiere et al., 2008). This spore-forming bacterium

*Corresponding author. E-mail: moh2055@yahoo.fr. Tel: 00213772812260.

Author(s) agree that this article remains permanently open access under the terms of the Creative Commons Attribution License 4.0 International License 
Table 1. Distribution of Bt isolates in samples collected from different localities of western Algeria.

\begin{tabular}{cl}
\hline Number of strain & Source \\
\hline 25 & Orchards of orange tree (Tlemcen city) \\
10 & Orchards of orange tree (Oran city) \\
12 & Orchards of orange tree (Ain Defla city) \\
13 & Orchards of orange tree (Sétif city) \\
2 & Reference strains \\
& $\cdot$ Bt BMG7 \\
& Bt HD22 \\
\hline
\end{tabular}

(Bt), well known for its insecticidal properties, is associated with its ability to produce crystal inclusions in sporulation. These inclusions are proteins encoded by cry genes and have been shown to be toxic to a variety of insects and other organisms like nematodes and protozoa (Konecka et al., 2007). The primary action of cry proteins is to lyse mid-gut epithelial cells through insertion into the target membrane and form pores (Bravo et al., 2007).

Once ingested, crystals are solubilized in the alkaline environment of mid-gut lumen and activated by host proteases (Brar et al., 2007). The cry genes of Bt strains are known to be related to their toxicity (Carozzi et al., 1991; Padidam, 1992), and identification of these genes by means of polymerase chain reaction (PCR) has been used to characterize and predict insecticidal activity of the strains (Ben-Dov et al.,1997; Hansen et al.,1998). The spectrum activity of Bt toxins continually increases as a result of the ongoing isolation of new strains around the world.

The objective of this work is to isolate and characterize local strains of $B$. thuringiensis, in order to find new specific strains in our orchards since these bacilli have the power to adapt themselves to the type of soil as well as the bioclimatic conditions of orchards in which they live. The local strains could be much active as biopesticide strains.

\section{MATERIALS AND METHODS}

\section{Description of strains}

Sixty strains belonging to the Bacillus group, isolated from orchard soils of orange trees of Tlemcen, Oran, Ain Defla and Setif cities as well as two other reference strains were used in this study (Table 1).

For every sample, $1 \mathrm{~g}$ of soil was put in a test tube containing 10 $\mathrm{ml}$ of sterile distilled water. Various concentrations $\left(10^{-1}, 10^{-2}, 10^{-4}\right.$ and $10^{-3}$ ) were prepared and stored in the ice. To eliminate the vegetative forms, the sample was heated to $80^{\circ} \mathrm{C}$ for $30 \mathrm{~min} .100 \mu \mathrm{l}$ of each concentration was spread over Luria and Bertani medium (AFNOR, 1996) at the rate of three plates by dilution, containing La $\mathrm{L}$-serine. The L-serine inhibits the growth of various species of Bacillus, except $B$. thuringiensis (Ongena and Jacques, 2007).

\section{Identification}

It was started by a microscopic study after a Gram staining. Only bacteria in the form of bacilli, spore-forming and Gram-positive were retained.

The biochemical study based on the classic gallery with the following characters: respiratory type, catalase, nitrate reductase, indole production, fermentation of glucose and mannitol was performed by using galleries Api 50CHB (bioMérieux, Marcy the Etoile, France).

\section{Search for parasporal crystal}

This step is devoted to the highlighting of parasporal crystal which allows the distinction between $B$. thuringiensis and other species of the $B$. cereus group. The same smears prepared for observation under the optical microscope were used without staining for scanning electron microscope examination (SEM) Hitachi TM 100.

\section{Molecular techniques}

The presence of parasporal crystals is a diagnostic characteristic for Bt strains (Konecka et al., 2007). The taxonomic identity of the toxic crystalliferous isolates was confirmed by amplification and partial sequencing of their 16S rDNA genes (Alvarez et al., 2009a). DNA extraction was realized from $1 \mathrm{ml}$ of culture incubated during night at $30^{\circ} \mathrm{C}$ in the medium (LB). The protocol described by Bravo et al. (1998) was used, followed by a universal 16S PCR targeting the gene coding for 16S rRNA using universal primers (Petiti, 2007). Indeed, ribosomal RNA (rRNA 16S) was the RNA component of the small ribosomal subunit of the prokaryotic $30 \mathrm{~S}$. The gene encoding this rRNA is the "16S rRNAgene" (Clarridge III, 2004), present in the whole bacterial species, in a variable number of copies (Petti, 2007; Woese, 1987). It consists of 1500 nucleotides and contains seven conserved regions and nine hypervariable regions (Chakravorty et al., 2007).

\section{PCR conditions}

The concentration of DNA used for PCR is between 10 and 30 $\mathrm{ng} / \mu \mathrm{L}$ (DNA concentration is determined using a spectrophotometer (Nanodrop TM 1000). The PCR program includes an initial denaturation step of $3 \mathrm{~min}$ at $94^{\circ} \mathrm{C}$, followed by 30 cycles with a denaturation of $1 \mathrm{~min}$, a hybridization of $30 \mathrm{~s}$ at $45^{\circ} \mathrm{C}$, followed by an extension of $2 \mathrm{~min}$ at $72^{\circ} \mathrm{C}$ for the primer pair, and finally a final elongation of $10 \mathrm{~min}$ at $72^{\circ} \mathrm{C}$. The reactive mixture consists of: 0.3 $\mu \mathrm{L}$ of each $16 \mathrm{~S}$ primer, $2.5 \mu \mathrm{l}$ of buffer containing $20 \mathrm{mM}$ of $\mathrm{MgCl}_{2}$, $0.2 \mu \mathrm{l}(25 \mathrm{mM})$ of dNTPs, $0.2 \mu \mathrm{l}$ of Taq polymerase, $20.5 \mu \mathrm{l}$ of water and $1 \mu \mathrm{L}$ of DNA. After that, $5 \mu \mathrm{l}$ of the PCR amplified product, mixed with bromophenol blue was analyzed by electrophoresis on agarose gel (1\%) after fixation with ethidium bromide. The gel was visualized with gel documentation system. Using a size marker, only the PCR products with a bands size corresponding to $1500 \mathrm{pb}$ are selected for sequencing (Table 2).

\section{Cloning and sequencing}

The retained PCR products were purified, cloned and sequenced. The samples were prepared according to the recommendations of the laboratory. The obtained sequences were compared by basic local alignement search tools (BLAST) software set on line by the National Center for Biotechnology Information (NCBI) (USA). 
Table 2. Sequences of the 16S rRNA genes primers used for PCR amplification.

\begin{tabular}{llcc}
\hline Primer & Sequence $\left(\mathbf{5}^{\prime}\right.$ to $\left.\mathbf{3}^{\prime}\right)$ & Annealing temperature $\left({ }^{\circ} \mathbf{C}\right)$ & Size $(\mathbf{b p})$ \\
\hline 16S rRNA-F & AGAGTTTGATGCTCAG & 56 & 1500 \\
16S rRNA-R & CTACGGCTACTTACGA & 56 & 1500 \\
\hline
\end{tabular}

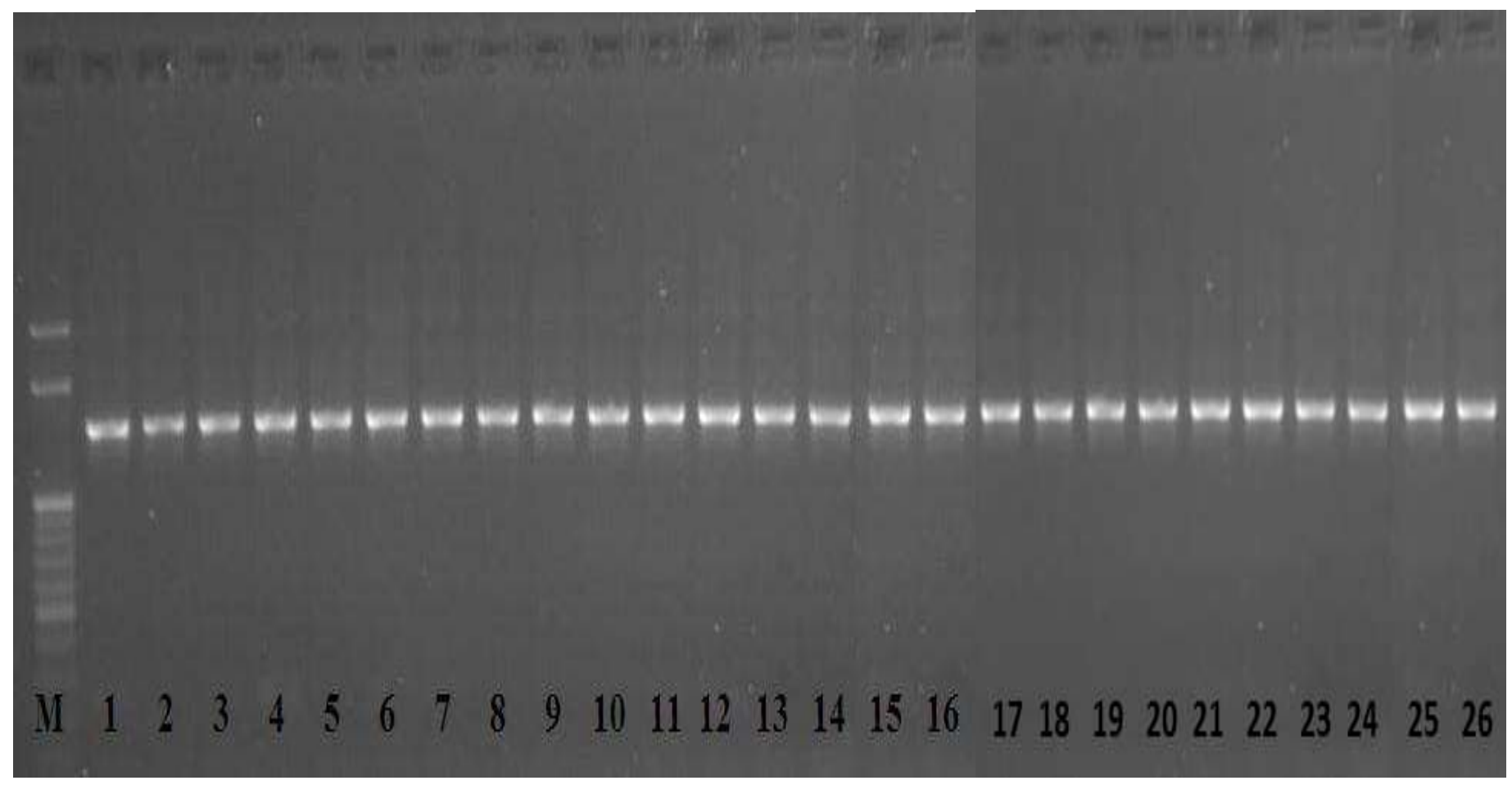

Figure 1. Agarose gel (1\%) electrophoresis for 16s rRNA -PCR. Lane M: DNA MW marker $1 \mathrm{~Kb}$, Lane 1: B. thuringiensis HD22, Lane 2: B. thrungiensis BMG7, Lane 3: S6DSP, Lane 4: S6DSG, Lane 5: S3DSG, Lane 6: S2DSP, Lane 7: S2DSG, Lane 8: BSUBG, Lane 9: BM5, Lane 10: BM3, Lane 11: BM14, Lane 12: BM13, Lane 13: BIS, Lane 14: BEN3, Lane 15: BEN1, Lane 16: B9, Lane 17: B8, Lane 18: B7, Lane 19: B6, Lane 20: B5, Lane 21: B4F, Lane 22: B3, Lane 23: B2C, Lane 24: B10, Lane 25: B1, Lane 26: 10).

\section{RESULTS}

\section{Strain identification}

The macroscopic characterization allowed distinguishing round colonies; flat (raised) with regular edges or not, opaque and white or beige.

The microscopic study, with Gram stain in fresh samples allowed us to notice that all strains are in the form of variable-sized rods (fine, medium and large); right with rounded edges and are Gram-positive, sporeforming and mobile. For the physiological tests, the result tends to show that all strains possess an optional catalase aero-anaerobic. The mini biochemical profile built on the basis of 50 tests of the API 50CHB gallery allowed one to distinguish a major group of 24 strains of various orchards (6 out of Tlemcen city, 5 of Oran city, 11 from Ain Defla city and finally 2 out of Sétif city). These strains present the largest number of positive characters, typical of species belonging to the $B$. cereus group. The analysis of these results by the Web API software gave the following identifications.

\section{Observation by scanning electron microscopy}

The strains observed by scanning electron microscope revealed that they belong to the group of $B$. cereus by the presence of parasporal crystal which is present only in $B$. thuringiensis (Figure 1), whereas this body is absent in the other bacteria of the group. The pictures taken by a scanning electron microscope show the presence of the crystal in 24 of our samples. The isolated Bt strains present parasporal crystals of cubic and rhombohedral shapes (Tables 3 and 4 ).

When the morphology of the crystals was examined, 
Table 3. Crystal protein morphology of native isolates of $B$. thuringiensis.

\begin{tabular}{ll}
\hline Isolate & Shape of crystal protein \\
\hline S6DSP & Cubical \\
S6DSG & Rhombohedral \\
S3DSG & Rhombohedral \\
S2DSP & Rhombohedral \\
S2DSG & Cubical \\
BSUBG & Cubical \\
BM5 & Cubical \\
BM3 & Cubical \\
BM14 & Cubical \\
BM13 & Cubical \\
BIS & Cubical \\
BEN3 & Cubical \\
BEN1 & Cubical \\
B9 & Cubical \\
B8 & Rhombohedral \\
B8 & Rhombohedral \\
B7 & Cubical \\
B6 & Rhombohedral \\
B5 & Rhombohedral \\
B4F & Cubical \\
B3 & Cubical \\
B2C & Rhombohedral \\
B10 & Cubical \\
B1 & Rhombohedral \\
10 & Rhombohedral \\
\hline &
\end{tabular}

crystalline bipiramidal forms were determined by scanning electron microscopy after purification of the crystals by a special ultracentrifugation procedure (Fast, 1972).

\section{Electrophoresis of PCR products}

The analysis of PCR products by electrophoresis on agarose gel (1\%) appears as shown in Figures 2 and 3.

\section{DISCUSSION}

Soil is a very important source of $B$. thuringiensis strain providing a large genetic resource for its use in the development of bio-insecticide to control insect pests that have not been previously reported to be susceptible to $B$. thuringiensis (Quesada-Morage et al., 2004).

On the bases of the dyeing properties, the production of endospore and its position, the mobility of strains, the presence of catalase and the absence of indole production, the strains that were isolated from the experimental orchards are assigned to the $B$. cereus group, which is the group I of the classification of Gordon et al. (1973).

The analyses by APIWEB software of API50 CHB galleries results have confirmed that all the 24 strains obtained belong to $B$. cereus group with species identification for 14 of them. Starting from the universal characteristic in the bacterial world, the amplification followed by sequencing of the 16S rRNA gene was used to identify the badly identified bacterial strains by some conventional techniques (Petti, 2007). The result of PCR $16 \mathrm{~S}$ corresponds to the identifications with API50 CHB gallery, and presents huge similarities with these results using the indicated on-line software.

The findings are supported by those obtained by Guinebretière et al. (2001), in terms of our strains and reference strains, but did not allow us to distinguish $B$. cereus from $B$. thuringiensis. These results confirm the observation made by Abderrahmani (2011) concerning the use of RNA $16 S$ for the identification of bacteria belonging to the cereus group. 

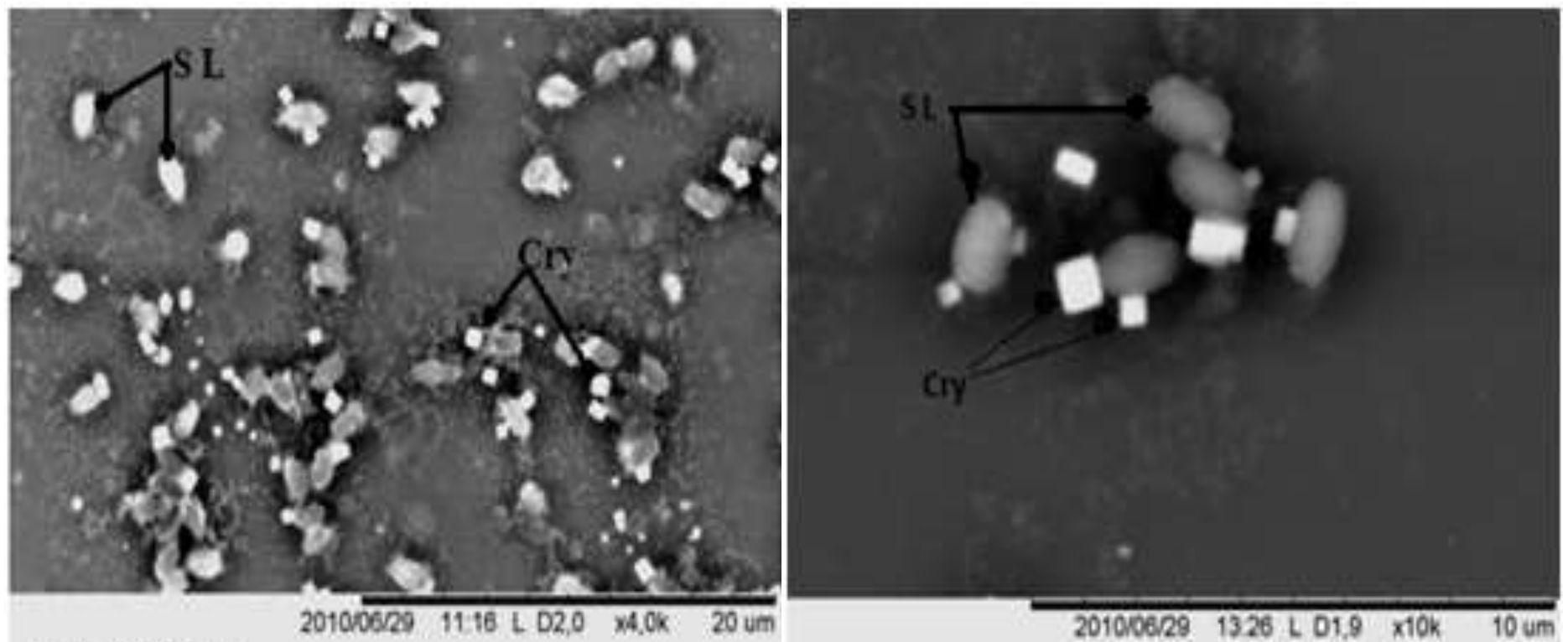

\section{TM1000-0101-00-10}

TM1000-0106-06-10

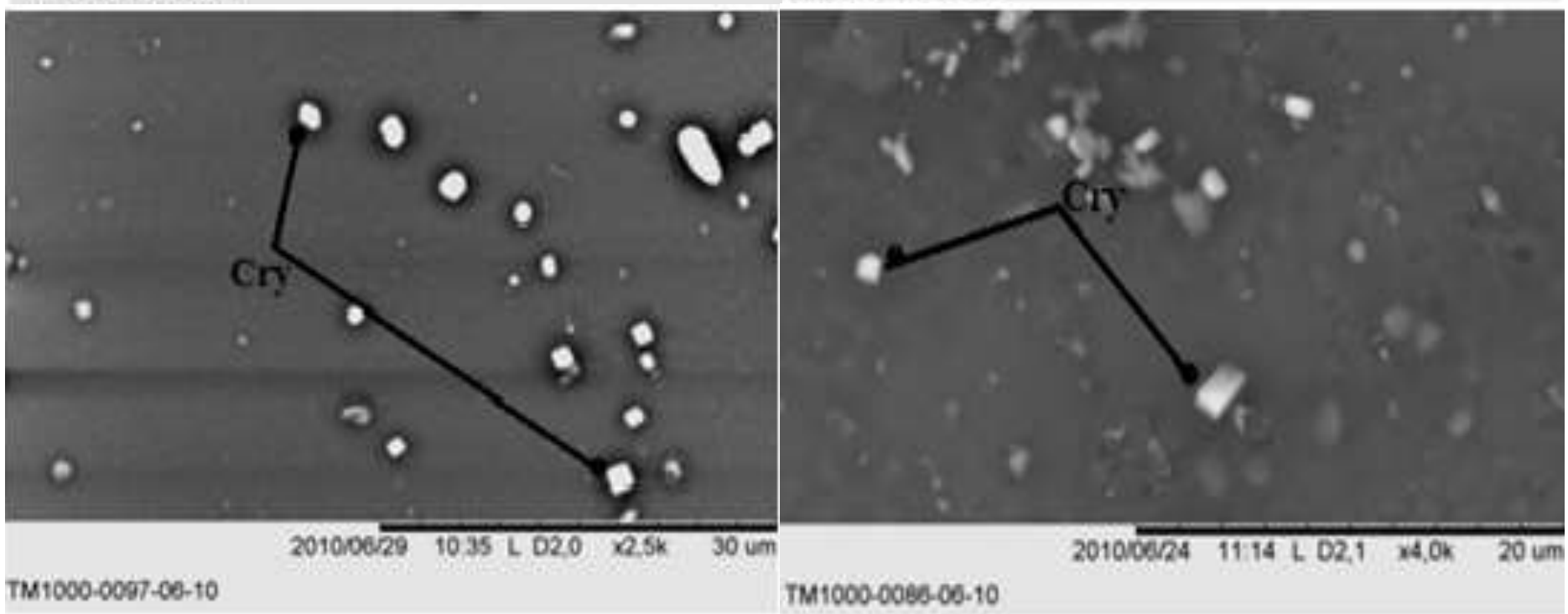

Figure 2. Photos taken by scanning electron microscope (SEM) (Cry: crystals and SL: free spores).

The authors could not discriminate between the two species until after the observation by scanning electron microscope, which allowed the visualization of the parasporal crystal which is present only in $B$. thuringiensis and responsible for entomopathogenic activity of this bacterium against several devastating species. The toxicity of $B$. thuringiensis did not depend on Cry gene content only because factors other than Cry proteins may contribute to toxicity as well as spore interaction with crystal protein and the other soluble toxins such as $\beta$-exotoxin (Porcar et al., 2000).

Martinez et al. (2004) suggested that the biological activity of a strain cannot be fully predicted on the basis of its Cry gene content alone. The relative proportion of the Cry proteins produced, their interaction, and the possible presence of undetected crystal proteins, such as cry1l genes are all important. These results show the diversity of the bacterial flora of Bacillus species in the Northern Algerian soil and the predominant presence of $B$. thuringiensis strain in the study areas, which could be considered as a potential reservoir of species used as a bio-pesticides for controlling insects pests without harming the beneficial ones.

\section{Conclusion}

This work confirmed that the bacterium, $B$. thuringiensis 
Table 4. Treatment of the sequences obtained after the PCR16S by the BLAST tool of the NCBI.

\begin{tabular}{|c|c|c|c|c|c|}
\hline Strain & Homology (\%) & Closest relative & Acc. $\mathrm{N}$. & Phylogenetic group & \\
\hline S6DSP & 99 & Bacillus pumilus & KJ526885.1 & $\begin{array}{l}\text { Bacteria; Firmicutes; Bacilli; Bacillales; } \\
\text { Bacillus; Bacillus cereus group. }\end{array}$ & Bacillaceae; \\
\hline S6DSG & 99 & Bacillus thuringiensis & KJ011876.1 & $\begin{array}{l}\text { Bacteria; Firmicutes; Bacilli; Bacillales; } \\
\text { Bacillus; Bacillus cereus group. }\end{array}$ & Bacillaceae; \\
\hline S3DSG & 100 & Bacillus mycoides & EU924505.1 & $\begin{array}{l}\text { Bacteria; Firmicutes; Bacilli; Bacillales; } \\
\text { Bacillus; Bacillus cereus group. }\end{array}$ & Bacillaceae; \\
\hline S2DSP & 99 & Bacillus subtilis & KU821696.1 & $\begin{array}{l}\text { Bacteria; Firmicutes; Bacilli; Bacillales; } \\
\text { Bacillus; Bacillus cereus group. }\end{array}$ & Bacillaceae; \\
\hline BSUBG & 99 & Bacillus subtilis & JQ361065.1 & $\begin{array}{l}\text { Bacteria; Firmicutes; Bacilli; Bacillales; } \\
\text { Bacillus; Bacillus cereus group. }\end{array}$ & Bacillaceae; \\
\hline BM5 & 99 & Bacillus subtilis & HM590703.1 & $\begin{array}{l}\text { Bacteria; Firmicutes; Bacilli; Bacillales; } \\
\text { Bacillus; Bacillus cereus group. }\end{array}$ & Bacillaceae; \\
\hline BM3 & 99 & Bacillus thuringiensis & HM068889.1 & $\begin{array}{l}\text { Bacteria; Firmicutes; Bacilli; Bacillales; } \\
\text { Bacillus; Bacillus cereus group. }\end{array}$ & Bacillaceae; \\
\hline BIS & 99 & Bacillus thuringiensis & KJ123714.1 & $\begin{array}{l}\text { Bacteria; Firmicutes; Bacilli; Bacillales; } \\
\text { Bacillus; Bacillus cereus group. }\end{array}$ & Bacillaceae; \\
\hline BEN3 & 100 & Bacillus thuringiensis & KJ769222.1 & $\begin{array}{l}\text { Bacteria; Firmicutes; Bacilli; Bacillales; } \\
\text { Bacillus; Bacillus cereus group. }\end{array}$ & Bacillaceae; \\
\hline BEN1 & 100 & Bacillus thuringiensis & CP010089.1 & $\begin{array}{l}\text { Bacteria; Firmicutes; Bacilli; Bacillales; } \\
\text { Bacillus; Bacillus cereus group. }\end{array}$ & Bacillaceae; \\
\hline B9 & 99 & Bacillus cereus & EU240373.1 & $\begin{array}{l}\text { Bacteria; Firmicutes; Bacilli; Bacillales; } \\
\text { Bacillus; Bacillus cereus group. }\end{array}$ & Bacillaceae; \\
\hline B8 & 99 & Bacillus cereus & KF758385.1 & $\begin{array}{l}\text { Bacteria; Firmicutes; Bacilli; Bacillales; } \\
\text { Bacillus; Bacillus cereus group. }\end{array}$ & Bacillaceae; \\
\hline B3 & 100 & Bacillus thuringiensis & СР010089.1 & $\begin{array}{l}\text { Bacteria; Firmicutes; Bacilli; Bacillales; } \\
\text { Bacillus; Bacillus cereus group. }\end{array}$ & Bacillaceae; \\
\hline $\mathrm{B} 2 \mathrm{C}$ & 99 & Bacillus subtilis & KM492825.1 & $\begin{array}{l}\text { Bacteria; Firmicutes; Bacilli; Bacillales; } \\
\text { Bacillus; Bacillus cereus group. }\end{array}$ & Bacillaceae; \\
\hline B10 & 100 & Bacillus cereus & EU240373.1 & $\begin{array}{l}\text { Bacteria; Firmicutes; Bacilli; Bacillales; } \\
\text { Bacillus; Bacillus cereus group. }\end{array}$ & Bacillaceae; \\
\hline B1 & 100 & Bacillus thuringiensis & KJ769218.1 & $\begin{array}{l}\text { Bacteria; Firmicutes; Bacilli; Bacillales; } \\
\text { Bacillus; Bacillus cereus group. }\end{array}$ & Bacillaceae; \\
\hline 10 & 99 & Bacillus cereus & EU240373.1 & $\begin{array}{l}\text { Bacteria; Firmicutes; Bacilli; Bacillales; } \\
\text { Bacillus; Bacillus cereus group. }\end{array}$ & Bacillaceae; \\
\hline
\end{tabular}

occurs naturally in Northern Algeria. This shows the possibility of using natural bio-insecticides, based on the local strains of $B$. thuringiensis which are against the harmful stages of the pests due to the various types oftoxins synthesized by this bacterium. The authors hope to continue this work with the aim to market the local strains of $B$. thuringiensis identified and put at the disposal of farmers. Indeed, in Algeria, the fight against fruit fly is based essentially on the use of insecticides.

\section{Conflict of Interests}

The authors have not declared any conflict of interests.

\section{ACKNOWLEDGEMENTS}

We thank the chef of the Laboratory of Biotechnology and bio-geo Valuation Higher Institute of Biotechnology of Sidi 


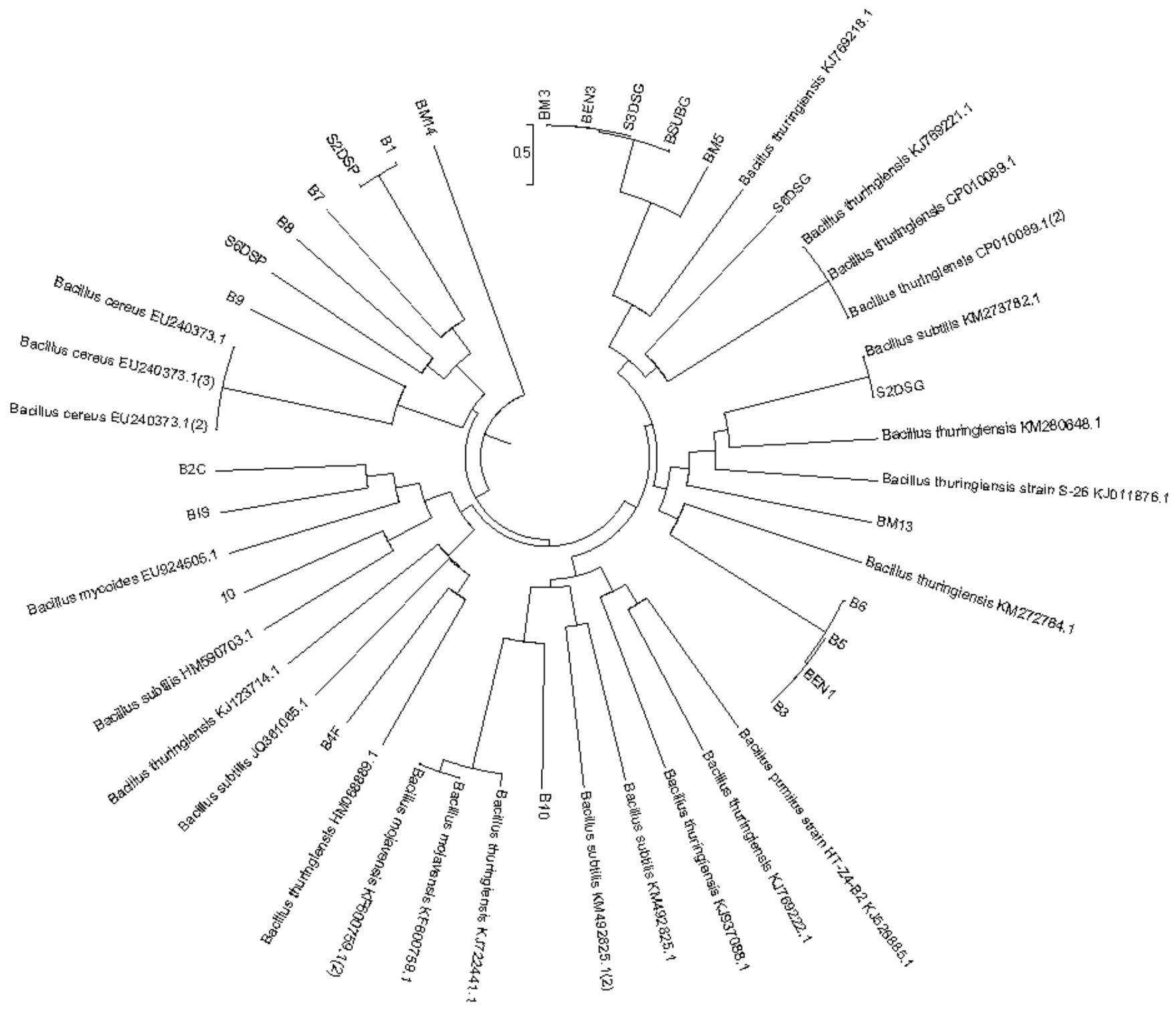

Figure 3. Dendrogram comparing PCR products of the field isolates and of the standard strains (DNA samples amplified in the presence of primers $16 \mathrm{~S}-\mathrm{F}$ and $16 \mathrm{~S}-\mathrm{R})$.

Thabet resources (Tunisia), to enable us to realize the studies in his laboratory.

\section{REFERENCES}

Abderrahmani A (2011). Identification of non-ribosomal synthesis mechanism of a new lipopeptide kurstakine and the study of its influence on the strains of Bacillus thuringiensis isolated phenotype in Algeria. Thesis of State University of Science and Technology Houari Boumediene, Algiers, Algeria. P 87.

AFNOR (1996). Standard Method for microbiological analysis of food products.

Ben-Dov E, Zaritski A, Dahan E, Barak Z, Sinai R, Manasherob R, Khamraeb A, Troitskaya E, Dubitsky A, Berezina N, Margalith $Y$ (1997). Extended screening by PCR for seven cry-group genes from field-collected strains of Bacillus thuringiensis. Appl. Environ.
Microbiol. 63:4883-4890.

Bravo A, Sarabia S, Lopez L, Ontiveros H, Abarca C, Ortiz A, Ortiz M, Lina L, Villalobos FJ, Pena G, Nunez-Valdez, Soberon M, Quintero $R$ (1998). Characterization of cry genes in a Mexican Bacillus thuringiensis strain collection. Appl. Environ. Microbiol. 64:49654972.

Bravo A, Gill S, Soberón M (2007). Mode of action of Bacillus thuringiensis Cry and Cyt toxins and their potential for insect control. Toxicon. 49:423-435.

Brar S, Verma M, Tyagi R, Surampalli R, Bernabé S, Valéro J (2007). Bacillus thuringiensis proteases: Production and rôle in growth, sporulation and synergism. Process. Biochem. J. 42:773-790.

Carozzi N, Kramer V, Warren G, Evola S, Koziel MG (1991). Prediction of chain reaction product profiles. Appl. Environ. Microbiol. 57:30573061.

Chakravorty S, Helb D, Burday Mr, Connell N, Alland D (2007). Characterization of cry genes in a Mexican Bacillus thuringiensis strain collection. Appl. Environ. Microbiol. 64(12):4965-4972. 
Clarridge JE III (2004). 16S rRNA Impact of Gene Sequence Analysis for Identification of Bacteria on Clinical Microbiology and Infectious Diseases. Clin. Microbiol. Rev. 17:840-862.

Fast PG (1972). The delta endotoxin of Bacillus thuringiensis III: a rapid method for separating parasporal bodies from spores. J. Invertebr. Pathol. 20:189-140.

Gordon RE (1973). The taxonomy of soil bacteria.In Gray and Parkinson (Editors). pp. 293-321.

Hansen B, Damgaard P, Eilenberg J, Pedersen JC (1998). Molecular and phenotypic characterization of Bacillus thuringiensis isolated from leaves and insects. J. Invertebr. Pathol. 71:106-114.

Konecka E, Kaznowski A, Ziemnicka J, Ziemnicki K (2007). Molecular and phenotypic characterization of Bacillus thuringiensis isolated during epizootics in Cydia pomonella L. J. Invertebr. Pathol. 94:5663.

Martinez C, Porcar M, Lopez A, de Escudero FJ, Perez-Llarena IR, Caballero P (2004). characterization of a Bacillus thuringiensis strain with a broad spectrum of activity against lepidopteran insect. Entomol. Exp. Appl. 111:71-77.

Ongena M, Jacques $P$ (2007). Bacillus lipopeptides: Versatile weapons for plant disease biocontrol. Trends. Microbiol. 16:116-125.
Padidam M (1992). The insecticid al crystal protein Cry1A (c) from Bacillus thuringiensis is highly toxic for Heliothis Armigera. J. Invertebr. Pathol. 59:109-111.

Petti CA (2007). Detection and identification of microorganisms by amplification and gene sequencing. Clin. Infect. Dis. 44:1108.

Porcar M, Martinéz C, and Caballero, P (2000). Host range and gene contents of Bacillus thuringiensis strains toxic towards Spodoptera exigua. Entomol. Exp. Appl. 97:339-346.

Quesada-Moraga E, Garcia-Tovar E, Valverde-Garcia P, and SantiagoAlvarez C (2004). Isolation, geographi- cal diversity and insecticidal activity of Bacillus thuringiensis from soils in Spain. Microbiol. Res. 159:59-71.

Rice PJ, Arthur EL Barefoot, AC (2007). Advances in Pesticide Environmental Fate and Exposure Assessments. J. Agric. Food. Chem. 55:5367-5376.

Woese CR (1987). Bacterial evolution. Microbiol. Rev. 51:222-270. 